\title{
Oral dosing of Recombinant Methioninase Is Associated With a 70\% Drop in PSA in a Patient With Bone-metastatic Prostate Cancer and 50\% Reduction in Circulating Methionine in a High-stage Ovarian Cancer Patient
}

\author{
QINGHONG HAN, YUYING TAN and ROBERT M. HOFFMAN
}

AntiCancer, Inc., San Diego, CA, U.S.A.

\begin{abstract}
Background/Aim: Methionine addiction is a general and fundamental hallmark of cancer. Methionine addiction can be targeted by methionine restriction (MR). Our laboratory has studied methionine addiction in cancer and MR for almost 50 years. The present study describes oral recombinant methioninase (o-rMETase), as a supplement, to induce MR in cancer patients. Patients and Methods: One patient, a 67-year-old female with high-stage ovarian cancer took o-rMETase twice a day at 250 units per dose for approximately one month. A second patient, a 76-year-old male with bone-metastatic prostate cancer, took o-rMETase twice a day at 250 units per dose during three months. Results: The first patient's circulating methionine levels decreased $50 \%$ within 4 hours of taking 250 units of orMETase. The second patient's PSA dropped approximately $70 \%$ over 3 months. During this time the patient's hemoglobin increased. Conclusion: o-rMETase has no side effects and is potentially efficacious. Future studies involving larger cohorts of patients with high-stage cancer are required to determine if o-rMETase, as a supplement, can increase survival and improve the quality of life.
\end{abstract}

Methionine addiction is a general and fundamental hallmark of cancer $(1,2)$. Methionine restriction (MR) selectively arrests cancer cells in the $S / G_{2}$-phase of the cell cycle and kills clonogenic cells which are equivalent to tumor-initiating cells and renders cancer cells sensitive to cell-cycle-specific drugs (3-6). Methionine addiction is due to cancer cells

This article is freely accessible online.

Correspondence to: Robert M. Hoffman, Ph.D., AntiCancer Inc. 7917 Ostrow St., San Diego, CA, U.S.A. Tel: +1 6198852284, e-mail: all@anticancer.com

Key Words: Methioninase, oral, methionine, methionine restriction prostate cancer, PSA, ovarian cancer, supplement, cancer patients. having an increased overall rate of transmethylation compared to normal cells that leads to methionine overuse, thereby depleting cellular pools of S-adenosylmethionine (7, 8 ). Overuse of methionine by cancer cells is called the "Hoffman effect" (9), a possibly stronger effect than the Warburg effect of overuse of glucose by cancer cells (10). DNA hypomethylation in human cancer, discovered in our laboratory (11-13), is probably the result of elevated (7) and altered transmethylation occurring in cancer cells (14). DNA hypomethylation leads to aneuploidy and subsequent cancer (15). Other fundamental characteristics of cancer are linked to methionine addiction (16).

We have used L-methioninedeamino-mercaptomethanelyase (methioninase) for methionine restriction (MR) (17). The methioninase gene from $P$. putida has been cloned and expressed in Escherichia coli and is termed recombinant methioninase (rMETase) (17).

Prostate cancer causes more cancer deaths in North American men except for lung cancer (18). There has been improvement in the early detection of prostate cancer due to the measurement of circulating prostate-specific antigen (PSA) and sophisticated imaging techniques (19). However, metastatic prostate cancer remains recalcitrant (19). Androgendeprivation therapy was first-line therapy from 1941 until 2015, when clinical trials showed that androgen-deprivation therapy combined with docetaxel improved survival $(20,21)$. However, survival of bone-metastatic prostate cancer patients is still low (18) and in need of improved therapy and a possible candidate is MR by methioninase.

Recombinant methioninase (rMETase) is effective against human cancer cell lines (lung, colon, kidney, melanoma, brain, and prostate) in vitro. rMETase had a mean $\mathrm{IC}_{50}$ for cancer cells 10 times lower than that for normal cell lines (22).

rMETase has arrested all cancer types tested in mouse models including patient-derived orthotopic xenograft (PDOX) models (23-49).

Oral administration of rMETase (o-rMETase) is highly effective on recalcitrant sarcoma, pancreatic cancer, colon 


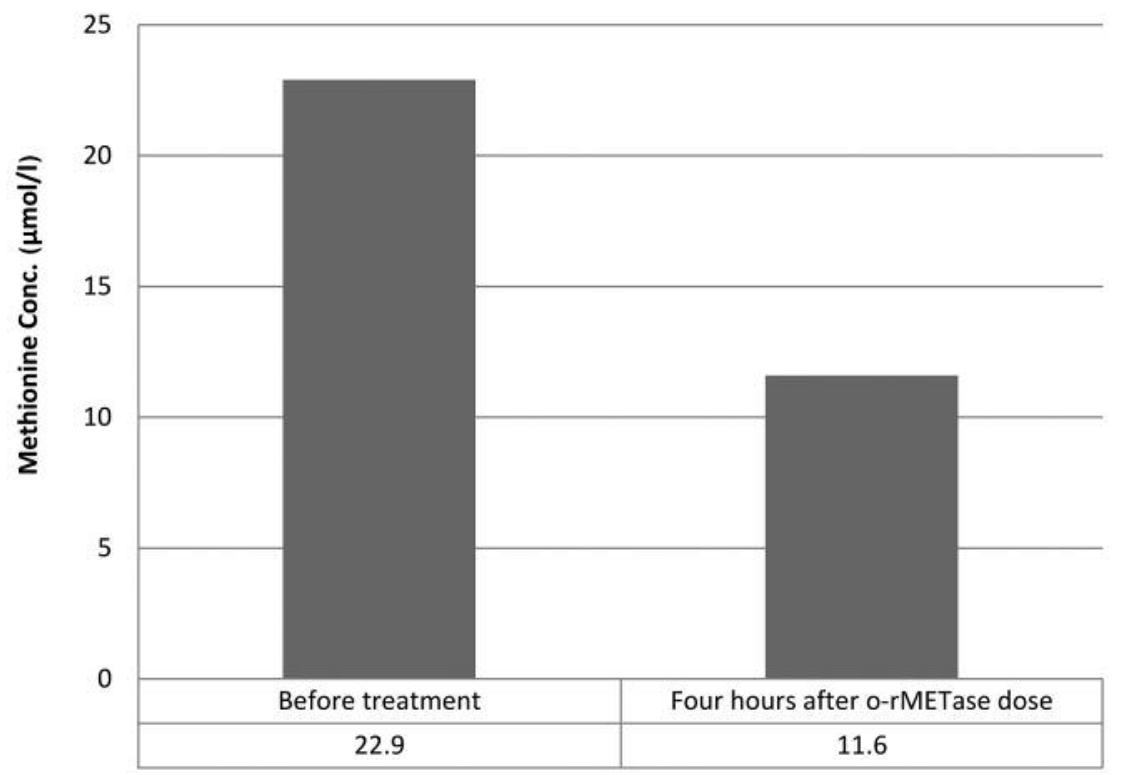

Figure 1. Circulating methionine levels $(\mu M)$ four hours after the ovarian cancer patient took 250 units o-rMETase on day 15. Methionine was measured as described in Materials and Methods.

cancer, and melanoma in PDOX models $(24,25,26,27,31$, $32,33,39,40,46)$.

Previous primate safety studies of PEGylated r-METase in macaque monkeys showed that i.v. administration of PEGylated rMETase depleted plasma methionine to $<5$ $\mu \mathrm{mol} / \mathrm{l}$ with transient anemia as the only side effect. Repeated treatment did not result in anaphylaxis (50).

A pilot phase I clinical trial was carried out to determine i.v. rMETase toxicity, and the extent of methionine depletion in high-stage cancer patients. Circulating methionine was lowered to $0.1 \mu \mathrm{M}$ by methioninase without toxicity $(51,52)$.

In the present study, oral recombinant methioninase (orMETase) was taken as a supplement by a 76-year-old male with bone-metastatic prostate cancer with a PSA of over 2000 and a 67-year-old female with high-stage ovarian cancer.

\section{Materials and Methods}

Oral rMETase production and formulation. rMETase was produced by fermentation of recombinant $E$. coli. and purified using column chromatography with DEAE-Sepharose FF, Sephacryl S-200HR, and ActiCleanEtox, resulting in $98 \%$ purity with low endotoxin and high yield (17). Pure methioninase was dissolved in PBS or water at $5 \mathrm{mg} / \mathrm{ml}$, which comprised one dose for oral administration after breakfast and dinner.

Methionine measurement. Methionine in plasma was derived with o-phthalaldehyde (OPA), and separated by HPLC using a Supelcosil LC-18-DB column $(25 \mathrm{~cm} \times 4.6 \mathrm{~mm})$, and eluted with tetrahydrofuran/ methanol/0.1 M sodium acetate, $\mathrm{pH} 7.0, \mathrm{v} / \mathrm{v} / \mathrm{v}=5 / 95 / 900$ and methanol. Detection was by fluorescence (53).
Prostate specific antigen (PSA). PSA was measured with the Abbott Architect; i2000 chemiluminescence immunoassay.

The ARCHITECT Total PSA assay is a chemiluminescent microparticle immunoassay (CMIA) for the quantitative determination of total PSA.

\section{Results}

A patient with high-stage ovarian cancer took o-rMETase twice a day at a dose of 250 units. After approximately one month of administration, the patient had no side effects. Within four hours of a dose of o-rMETase the patient's circulating methionine decreased 50\% (Figure 1).

A second patient with bone-metastatic prostate cancer and a PSA of over 2000 took o-rMETase twice a day at a dose of 250 units for three months, thus far. During this time the PSA levels decreased approximately $70 \%$ (Figure 2A, B). The patient's hemoglobin levels increased from 7.4 to $8.7 \mathrm{~g} / \mathrm{dl}$ during this time (Figure 3 ). No side effects were observed.

\section{Discussion}

Methionine addiction is a general and fundamental hallmark of cancer $(1,2)$. It has been studied for over 60 years, since Sugimura (54) observed that MR diets reduced significantly the growth of tumors growing in rats. In the early and midseventies, cell culture experiments showed that cancer cells had an elevated requirement for methionine $(55,56)$. It was thought that cancer cells were simple auxotrophs that could 
A

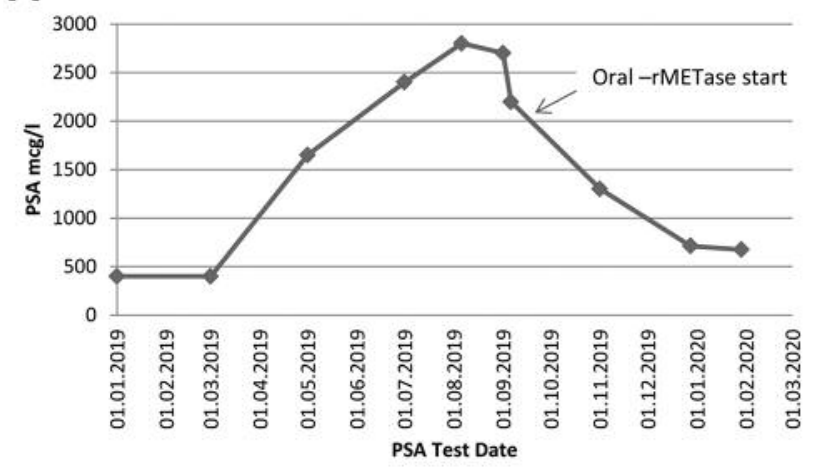

B

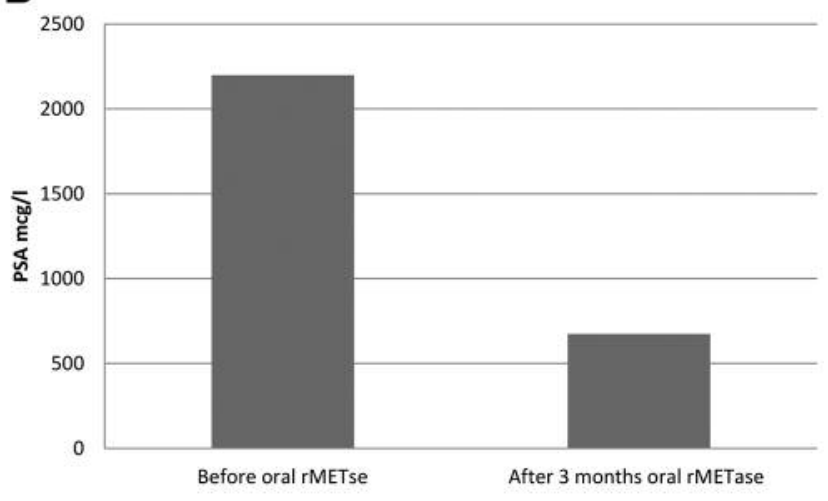

Figure 2. PSA levels. A). PSA levels in the prostate cancer patient were measured at the indicated times and o-rMETase was started at the indicated time, twice a day at 250 units per dose: B). Summary bar graph of PSA levels at the start of o-rMETase use and after three months.

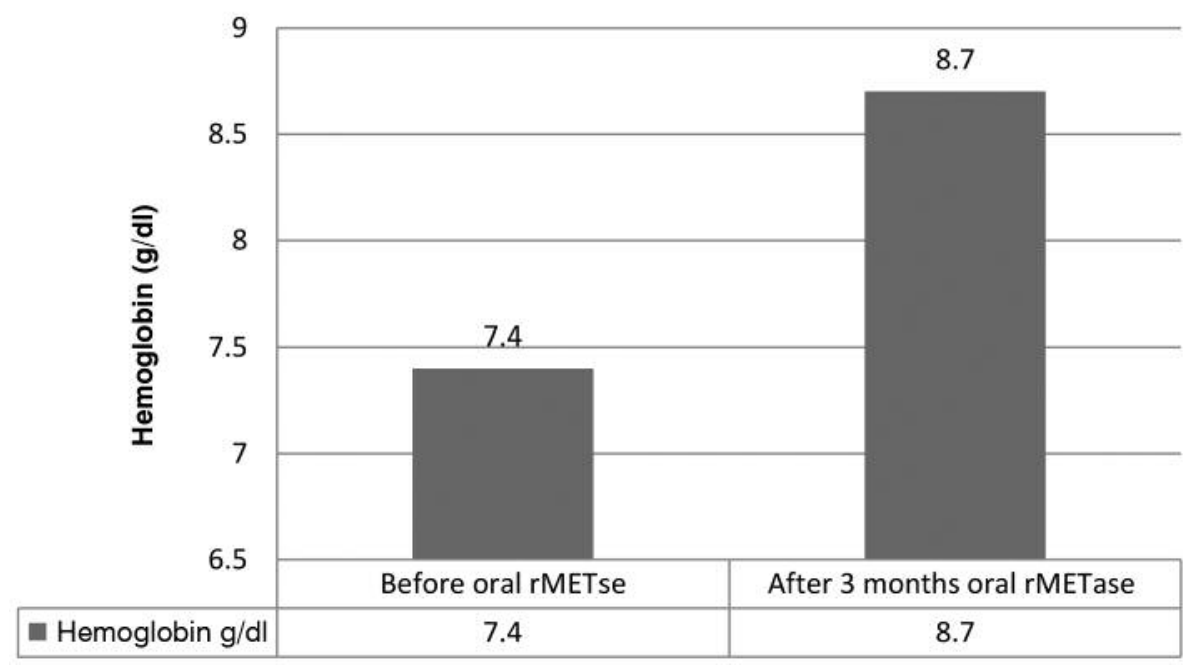

Figure 3. Hemoglobin levels in the prostate cancer patient before and after taking o-rMETase for 3 months.

not synthesize methionine from homocysteine. However, we showed that cancer cells synthesize as much methionine or more than normal cells $(2,8)$. It became clear that cancer cells were addicted to methionine, which we showed was due to excess transmethylation (7).

Recently papers have come out claiming novelty regarding methionine addiction $(57,58)$, about which we published long ago (1-8, 59-62).

The first methioninase was isolated by Kreis from Clostridium (63). A more stable methioninase was subsequently isolated in Japan by Tanaka et al. (64) from Pseudomonas putida, which we later cloned and developed into a very effective anticancer agent (17). Many studies have demonstrated that rMETase is efficacious in cancer cells in vitro, cell-line tumors growing in mice, and PDOX models (23-49). However, it was difficult to develop an injectable rMETase into a drug since it is a bacterial protein that elicited strong immune reactions in monkeys, which could be partially overcome by PEGyletion (50).

A major breakthrough occurred in 2017 when we observed that rMETase (31), despite being a very large protein, could be administered very effectively orally (24, $25,26,27,32,33,39,40,46)$. o-rMETase restricts methionine in the gut, and thereby lowers the levels of methionine in the bloodstream (33). o-rMETase itself did not enter the bloodstream making it a far safer agent than injectable methioninase. Therefore, our strategy was to develop methioninase as an oral supplement. 
In the present studies, we showed that oral methioninase greatly reduced circulating methionine in a human subject with high-stage ovarian cancer (Figure 1). Therefore, we then tested o-rMETase on an advanced bone-metastatic prostate cancer patient with an extremely high PSA. The patient received o-rMETase for three months without any side effects and his PSA dropped approximately by $70 \%$ (Figure 2). The patient's overall performance was improved, with increased hemoglobin levels (Figure 3) and the patient was feeling much better during the time he was taking oral methioninase. After the patient started to take oral methioninase, he also began oral dexamethasone (65), which may have helped to lower PSA levels. We will recruit additional patients with high-stage cancer for the testing of oral methianinase as a supplement.

\section{Conflicts of Interest}

The Authors report no conflicts of interest related to this study.

\section{Authors' Contributions}

Qinghong Han and Yuying Tan performed all experiments including the production of methioninase. Robert M. Hoffman and Qinghong Han wrote and revised the paper.

\section{Acknowledgements}

This paper is dedicated to the memory of John Mays, AR Moossa, M. D., Sun Lee, M. D. Professor Li Jiaxi and Masaki Kitajima, M. D.

\section{References}

1 Hoffman RM: Development of recombinant methioninase to target the general cancer-specific metabolic defect of methionine dependence: a 40-year odyssey. Expert Opin Biol Ther 15: 21-31, 2015. PMID: 2543928. DOI: 10.1517/14712598.2015.963050

2 Hoffman RM and Erbe RW: High in vivo rates of methionine biosynthesis in transformed human and malignant rat cells auxotrophic for methionine. Proc Natl Acad Sci USA 73: 15231527, 1976. PMID: 179090.

3 Hoffman RM and Jacobsen SJ: Reversible growth arrest in simian virus 40 transformed human fibroblasts. Proc Natl Acad Sci USA 77: 7306-7310, 1980. PMID: 6261250.

4 Guo H, Lishko VK, Herrera H, Groce A, Kubota T and Hoffman RM: Therapeutic tumor specific cell cycle block induced by methionine starvation in vivo. Cancer Res 53: 5676-5679, 1993. PMID: 8242623.

5 Yano S, Li S, Han Q, Tan Y, Bouvet M, Fujiwara T and Hoffman RM: Selective methioninase-induced trap of cancer cells in $\mathrm{S} / \mathrm{G} 2$ phase visualized by FUCCI imaging confers chemosensitivity. Oncotarget 5: 8729-8736, 2014. PMID: 25238266. DOI: 10.18632/oncotarget.2369

6 Stern PH and Hoffman RM: Enhanced in vitro selective toxicity of chemotherapeutic agents for human cancer cells based on a metabolic defect. J Natl Cancer Inst 76: 629-639, 1986. PMID: 3457200 .
7 Stern PH and Hoffman RM: Elevated overall rates of transmethylation in cell lines from diverse human tumors. In Vitro 20: 663-670, 1984. PMID: 6500606. DOI: 10.1007/bf02619617

8 Coalson DW, Mecham JO, Stern PH and Hoffman RM: Reduced availability of endogenously synthesized methionine for $\mathrm{S}$ adenosylmethionine formation in methionine dependent cancer cells. Proc Natl Acad Sci USA 79: 4248-4251, 1982. PMID: 6289297.

9 Hoffman RM: Is the Hoffman effect for methionine overuse analogous to the Warburg effect for glucose overuse in cancer? Methods Mol Biol 1866: 273-278, 2019. PMID: 30725423. DOI: 10.1007/978-1-4939-8796-2_21.

10 Hoffman RM: 1-(Methyl-11C) Methionine-positron-emission tomography (MET-PET). Methods Mol Biol 1866: 267-271, 2019. PMID: 30725422. DOI: 10.1007/978-1-4939-8796-2_20

11 Diala ES and Hoffman RM: Hypomethylation of HeLa cell DNA and the absence of 5 methylcytosine in SV40 and adenovirus (type 2) DNA: analysis by HPLC. Biochem Biophys Res Commun 107: 19-26, 1982. PMID: 6289818. DOI: 10.1016/0006-291x(82)91663-1

12 Hoffman RM: The wayward methyl group and the cascade to cancer. Cell Cycle 16: 825-829, 2017. PMID: 28318368. DOI: 10.1080/15384101.2017.1304330

13 Hoffman RM: Is DNA methylation the new guardian of the genome? Mol Cytogenet 10: 11, 2017. PMID: 28396696. DOI: 10.1186/s13039-017-0314-8

14 Tisdale M: Effect of methionine deprivation on methylation and synthesis of molecules. Br J Cancer 42: 121-128, 1980. PMID: 7426323. DOI: $10.1038 /$ bjc. 1980.210

15 Bloomfield M and Duesberg P: Inherent variability of cancerspecific ancupoidy geneiates metastases. Mol Cytogenet 9: 90, 2016.PMID: 28018487. DOI: 10.1186/s13039-016-0297

16 Hoffman RM, Jacobsen SJ and Erbe RW: Reversion to methionine independence in simian virus 40-transformed human and malignant rat fibroblasts is associated with altered ploidy and altered properties of transformation. Proc Natl Acad Sci USA 76: 1313-1317, 1979. PMID: 220612. DOI: 10.1073/pnas.76.3.1313

17 Tan Y, Xu M, Tan X, Tan X, Wang X, Saikawa Y, Nagahama T, Sun X, Lenz M and Hoffman RM: Overexpression and largescale production of recombinant L-methionine-alpha-deaminogamma-mercaptomethane-lyase for novel anticancer therapy. Protein Expr Purif 9: 233-245, 1997. PMID: 9056489. DOI: 10.1006/prep.1996.0700

18 Siegal RL, Miller RD and Jemal A: Cancer statistics, 2020. CA Cancer J Clin 70: 7-30, 2020. DOI: 10.3322/caac.21590

19 Sartor O and De Bono JS: Metastatic prostate cancer. N Engl J Med 387: 645-657, 2018. PMID: 29412780. DOI: 10.1056/NEJMra1701695

20 Sweeney CJ, Chen YH, Carducci M, Liu G, Jarrard DF, Eisenberger M, Wong YN, Hahn N, Kohli M, Cooney MM, Dreicer R, Vogelzang NJ, Picus J, Shevrin D, Hussain M, Garcia JA and DiPaola RS: Chemohormonal therapy in metastatic hormone-sensitive prostate cancer. N Engl J Med 373: 737-746, 2015. PMID: 26244877. DOI: 10.1007/s00120-015-3970-5

21 James ND, Sydes MR, Clarke NW, Mason MD, Dearnaley DP, Spears MR, Ritchie AW, Parker CC, Russell JM, Attard G, de Bono J, Cross W, Jones RJ, Thalmann G, Amos C, Matheson D, Millman R, Alzouebi M, Beesley S, Birtle AJ, Brock S, Cathomas R, Chakraborti P, Chowdhury S, Cook A, Elliott T, Gale J, Gibbs S, Graham JD, Hetherington J, Hughes R, Laing 
R, McKinna F, McLaren DB, O'Sullivan JM, Parikh O, Peedell C, Protheroe A, Robinson AJ, Srihari N, Srinivasan R, Staffurth J, Sundar S, Tolan S, Tsang D, Wagstaff J and Parmar MK; STAMPEDE investigators: Addition of docetaxel, zoledronic acid, or both to first-line long-term hormone therapy in prostate cancer (STAMPEDE): survival results from an adaptive, multiarm, multistage, platform randomised controlled trial. Lancet 387: 1163-1177, 2016. PMID: 26719232. DOI: 10.1016/S0140-6736(15)01037-5

22 Tan Y, Xu M and Hoffman RM: Broad selective efficacy of recombinant methioninase and polyethylene glycol-modified recombinant methioninase on cancer cells in vitro. Anticancer Res 30: 1041-1045, 2010. PMID: 20530407.

23 Igarashi K, Kawaguchi K, Kiyuna T, Miyake K, Murakami T, Yamamoto K, Hayashi K, Kimura H, Miwa S, Tsuchiya H and Hoffman RM: Effective metabolic targeting of human osteosarcoma cells in vitro and in orthotopic nude-mouse models with recombinant methioninase, Anticancer Res 37: 4807-4812, 2017. PMID: 28870899. DOI: 10.21873/anticanres.11887

24 Higuchi H, Han Q, Miyake K, Oshiro H, Sugisawa N, Tan Y, Yamamoto N, Hayashi K, Kimura H, Miwa S, Igarashi K, Bouvet M, Singh SR, Tsuchiya $\mathrm{H}$ and Hoffman RM: Combination of oral recombinant methioninase and decitabine arrests a chemotherapy-resistant undifferentiated soft-tissue sarcoma patient-derived orthotopic xenograft mouse model. Biochem Biophys Res Commun 523: 135-139, 2020. PMID: 31839218. DOI: 10.1016/j.bbrc.2019.12.024

25 Higuchi T, Sugisawa N, Yamamoto J, Oshiro H, Han Q, Yamamoto N, Hayashi K, Kimura H, Miwa S, Igarashi K, Tan Y, Kuchipudi S, Bouvet M, Singh SR, Tsuchiya H and Hoffman RM: The combination of oral-recombinant methioninase and azacitidine arrests a chemotherapy-resistant osteosarcoma patient-derived orthotopic xenograft mouse model. Cancer Chemother Pharmacol 85: 285-291, 2019. PMID: 31705268. DOI: $10.1007 / \mathrm{s} 00280-019-03986-0$.

26 Oshiro H, Tome Y, Kiyuna T, Yoon SN, Lwin TM, Han Q, Tan Y, Miyake K, Higuchi T, Sugisawa N, Katsuya Y, Park JH, Zang Z, Razmjooei S, Bouvet M, Clary B, Singh SR, Kanaya F, Nishida $\mathrm{K}$ and Hoffman RM: Oral recombinant methioninase overcomes colorectal-cancer liver metastasis resistance to the combination of 5-fluorouracil and oxaliplatinum in a patient-derived orthotopic xenograft mouse model. Anticancer Res 39: 4667-4671, 2019. PMID: 31519565. DOI: 10.21873/anticanres. 13648

27 Higuchi T, Oshiro H, Miyake K, Sugisawa N, Han Q, Tan Y, Park J, Zhang Z, Razmjooei S, Yamamoto N, Hayashi K, Kimura H, Miwa S, Igarashi K, Bouvet M, Chawla SP, Singh SR, Tsuchiya $\mathrm{H}$ and Hoffman RM: Oral recombinant methioninase, combined with oral caffeine and injected cisplatinum, overcome cisplatinum-resistance and regresses patient-derived orthotopic xenograft model of osteosarcoma. Anticancer Res 39: 4653-4657, 2019. PMID: 31519563. DOI: 10.21873/anticanres.13646

28 Kawaguchi K, Han Q, Li S, Tan Y, Igarashi K, Murakami K, Unno $M$ and Hoffman RM: Efficacy of recombinant methioninase (rMETase) on recalcitrant cancer patient-derived orthotopic xenograft (PDOX) mouse models: A review. Cells 8: 410-423, 2019. PMID: 31052611. DOI: 10.3390/cells8050410

29 Miyake K, Kiyuna T, Li S, Han Q, Tan Y, Zhao M, Oshiro H, Kawaguchi K, Higuchi T, Zhang Z, Razmjooei S, Barangi M, Wangsiricharoen S, Murakami T, Singh AS, Li Y, Nelson SD, Eilber FC, Bouvet M, Hiroshima Y, Chishima T, Matsuyama R,
Singh SR, Endo I and Hoffman RM: Combining tumor-selective bacterial therapy with Salmonella typhimurium A1-R and cancer metabolism targeting with oral recombinant methioninase regressed an Ewing's sarcoma in a patient-derived orthotopic xenograft model. Chemotherapy 63: 278-283, 2018. PMID: 30673664. DOI: 10.1159/000495574

30 Igarashi K, Kawaguchi K, Kiyuna T, Miyake K, Miyaki M, Yamamoto N, Hayashi K, Kimura H, Miwa S, Higuchi T, Singh AS, Chmielowski B, Nelson SD, Russell TA, Eckardt MA, Dry SM, Li Y, Singh SR, Chawla SP, Eilber FC, Tsuchiya H and Hoffman RM: Metabolic targeting with recombinant methioninase combined with palbociclib regresses a doxorubicin-resistant dedifferentiated liposarcoma, Biochem. Biophys Res Commun 506: 912-917, 2018. PMID: 30392912. DOI: 10.1016/j.bbrc.2018.10.119

31 Higuchi T, Kawaguchi K, Miyake K, Han Q, Tan Y, Oshiro H, Sugisawa N, Zhang Z, Razmjooei S, Yamamoto N, Hayashi K, Kimura H, Miwa S, Igarashi K, Chawla SP, Singh AS, Eilber FC, Singh SR, Tsuchiya H and Hoffman RM: Oral recombinant methioninase combined with caffeine and doxorubicin induced regression of a doxorubicin-resistant synovial sarcoma in a PDOX mouse model. Anticancer Res 38: 5639-5644, 2018. PMID: 30275182. DOI: 10.21873/anticanres.12899

32 Kawaguchi K, Higuchi T, Li S, Han Q, Tan Y, Igarashi K, Zhao M, Miyake K, Kiyuna T, Miyake M, Ohshiro H, Sugisawa N, Zhang Z, Razmjooei S, Wangsiricharoen S, Chmielowski B, Nelson SD, Russell TA, Dry SM, Li Y, Eckardt MA, Singh AS, Singh SR, Eilber FC, Unno M and Hoffman RM: Combination therapy of tumor-targeting Salmonella typhimurium A1-R and oral recombinant methioninase regresses a BRAF-V600Enegative melanoma. Biochem Biophys Res Commun 503: 30863092, 2018. PMID: 30166061. DOI: 10.1016/j.bbrc.2018.08.097.

33 Kawaguchi K, Higuchi T, Li S, Han Q, Tan Y, Igarashi K, Zhao M, Miyake K, Kiyuna T, Miyake M, Ohshiro H, Sugisawa N, Zhang Z, Razmjooei S, Wangsiricharoen S, Chmielowski B, Nelson SD, Russell TA, Dry SM, Li Y, Eckardt MA, Singh AS, Singh SR, Eilber FC, Unno $M$ and Hoffman RM: Oral recombinant methioninase (o-rMETase) is superior to injectable rMETase and overcomes acquired gemcitabine resistance in pancreatic cancer. Cancer Lett 432: 251-259, 2018. PMID: 29928962. DOI: 10.1016/j.canlet.2018.06.016

34 Kawaguchi K, Miyake K, Han Q, Li S, Tan Y, Igarashi K, Lwin TM, Higuchi T, Kiyuna T, Miyake M, Oshiro H, Bouvet M, Unno M and Hoffman RM: Targeting altered cancer methionine metabolism with recombinant methioninase (rMETase) overcomes partial gemcitabine-resistance and regresses a patientderived orthotopic xenograft (PDOX) nude mouse model of pancreatic cancer. Cell Cycle 17: 2019-2026, 2018. PMID: 29623758. DOI: 10.1080/15384101.2018.1445907

35 Kawaguchi K, Miyake K, Han Q, Li S, Tan Y, Igarashi K, Lwin TM, Higuchi T, Kiyuna T, Miyake M, Oshiro H, Bouvet M, Unno $M$ and Hoffman RM: Intra-tumor L-methionine level highly correlates with tumor size in both pancreatic cancer and melanoma patient-derived orthotopic xenograft (PDOX) nudemouse models. Oncotarget 9: 11119-11125, 2018. PMID: 29541401. DOI: 10.18632 /oncotarget.24264

36 Kawaguchi K, Igarashi K, Li S, Han Q, Tan Y, Kiyuna T, Miyake K, Murakami T, Chmielowski B, Nelson SD, Russell TA, Dry SM, Li Y, Unno M, Eilber FC and Hoffman RM: Combination treatment with recombinant methioninase enables temozolomide 
to arrest a BRAF V600E melanoma in a patient-derived orthotopic xenograft (PDOX) mouse model. Oncotarget 8: 85516-85525, 2017. PMID: 29156737. DOI: 10.18632/oncotarget.20231

37 Igarashi K, Kawaguchi K, Kiyuna T, Miyake K, Miyake M, Li S, Han Q, Tan Y, Zhao M, Li Y, Nelson SD, Dry SM, Singh AS, Elliott IA, Russell TA, Eckardt MA, Yamamoto N, Hayashi K, Kimura H, Miwa S, Tsuchiya H, Eilber FC and Hoffman RM: Tumor-targeting Salmonella typhimurium A1-R combined with recombinant methioninase and cisplatinum eradicates an osteosarcoma cisplatinum-resistant lung metastasis in a patientderived orthotopic xenograft (PDOX) mouse model: decoy, trap and kill chemothe. Cell Cycle 17: 801-809, 2018. PMID: 29481803. DOI: 10.1016/j.bbrc.2018.02.174

38 Igarashi K, Kawaguchi K, Li S, Han Q, Tan Y, Murakami T, Kiyuna T, Miyake K, Miyake M, Singh AS, Eckardt MA, Nelson SD, Russell TA, Dry SM, Li Y, Yamamoto N, Hayashi K, Kimura H, Miwa S, Tsuchiya H, Singh SR, Eilber FC and Hoffman RM: Recombinant methioninase in combination with doxorubicin (DOX) overcomes first-line DOX resistance in a patient-derived orthotopic xenograft nude-mouse model of undifferentiated spindle-cell sarcoma. Cancer Lett 417: 168-173, 2018. PMID: 29306021. DOI: 10.1016/j.canlet.2017.12.028

39 Kawaguchi K, Han Q, Li S, Tan Y, Igarashi K, Kiyuna T, Miyake K, Miyake M, Chmielowski B, Nelson SD, Russell TA, Dry SM, Li Y, Singh AS, Eckardt MA, Unno M, Eilber FC and Hoffman RM: Targeting methionine with oral recombinant methioninase (o-rMETase) arrests a patient-derived orthotopic xenograft (PDOX) model of BRAF-V600E mutant melanoma: implications for chronic clinical cancer therapy and prevention. Cell Cycle 17: 356-361, 2018. PMID: 29187018. DOI: 10.1080/15384101.2017.1405195

40 Park JH, Han Q, Zhao M, Tan Y, Higuchi T, Yoon SN, Sugisawa N, Yamamoto J, Bouvet M, Clary B, Singh SR and Hoffman RM: Oral recombinant methioninase combined with oxaliplatinum and 5-fluorouracil regressed a colon cancer growing on the peritoneal surface in a patient-derived orthotopic xenograft mouse model. Tissue Cells 61: 109-114, 2019. PMID: 31759402. DOI: 10.1016/j.tice.2019.09.006

41 Igarashi K, Li S, Han Q, Tan Y, Kawaguchi K, Murakami T, Kiyuna T, Miyake K, Li Y, Nelson SD, Dry SM, Singh AS, Elliott IA, Russell TA, Eckardt MA, Yamamoto N, Hayashi K, Kimura H, Miwa S, Tsuchiya H, Eilber FC and Hoffman RM: Growth of doxorubicin-resistant undifferentiated spindle-cell sarcoma PDOX is arrested by metabolic targeting with recombinant methioninase. J Cell Biochem 119: 3537-3544, 2018. PMID: 29143983. DOI: $10.1002 /$ jcb.26527

42 Murakami T, Li S, Han Q, Tan Y, Kiyuna T, Igarashi K, Kawaguchi K, Hwang HK, Miyake K, Singh AS, Nelson SD, Dry SM, Li Y, Hiroshima Y, Lwin TM, DeLong JC, Chishima T, Tanaka K, Bouvet M, Endo I, Eilber FC and Hoffman RM: Recombinant methioninase effectively targets a Ewing sarcoma in a patient-derived ort.hotopic xenograft (PDOX) nude-mouse model. Oncotarget 8: 35630-35638, 2017. PMID: 28404944. DOI: $10.18632 /$ oncotarget.15823

43 Yano S, Takehara K, Zhao M, Tan Y, Han Q, Li S, Bouvet M, Fujiwara T and Hoffman RM: Tumor-specific cell-cycle decoy by Salmonella typhimurium A1-R combined with tumor-selective cellcycle trap by methioninase overcome tumor intrinsic chemoresistance as visualized by FUCCI imaging. Cell Cycle 15: 1715-1723, 2016. PMID: 27152859. DOI:10.1080/15384101.2016.1181240
44 Igarashi K, Kawaguchi K, Li S, Han Q, Tan Y, Gainor E, Kiyuna T, Miyake K, Miyake M, Higuchi T, Oshiro H, Singh AS, Eckardt MA, Nelson SD, Russell TA, Dry SM, Li Y, Yamamoto N, Hayashi K, Kimura H, Miwa S, Tsuchiya H, Eilber FC and Hoffman RM: Recombinant methioninase combined with doxorubicin (DOX) regresses a DOX-resistant synovial sarcoma in a patient-derived orthotopic xenograft (PDOX) mouse model. Oncotarget 9: 19263-19272, 2018. PMID: 29721200. DOI: 10.18632/oncotarget.24996

45 Kawaguchi K, Igarashi K, Li S, Han Q, Tan Y, Miyake K, Kiyuna T, Miyake M, Murakami T, Chmielowski B, Nelson SD, Russell TA, Dry SM, Li Y, Unno M, Eilber FC and Hoffman RM: Recombinant methioninase (rMETase) is an effective therapeutic for BRAF-V600E-negative as well as -positive melanoma in patient-derived orthotopic xenograft (PDOX) mouse models. Oncotarget 9: 915-923, 2018. PMID: 29416666. DOI: 10.18632 /oncotarget.23185

46 Park JH, Zhao M, Han Q, Sun Y, Higuchi T, Sugisawa N, Yamamoto J, Singh SR, Clary B, Bouvet M and Hoffman RM: Efficacy of oral recombinant methioninase combined with oxaliplatinum and 5-fluorouracil on primary colon cancer in a patient-derived orthotopic xenograft mouse model. Biochem Biophys Res Commun 518: 306-310, 2019. PMID: 31421825. DOI: 10.1016/j.bbrc.2019.08.051

47 Yoshioka T, Wada T, Uchida N, Maki H, Yoshida H, Ide N, Kasai H, Hojo K, Shono K, Maekawa R, Yagi S, Hoffman RM and Sugita K: Anticancer efficacy in vivo and in vitro, synergy with 5-fluorouracil, and safety of recombinant methioninase. Cancer Res 58: 2583-2587, 1998. PMID: 31421825. DOI: 10.1016/j.bbrc.2019.08.051.

48 Kokkinakis DM, Hoffman RM, Frenkel EP, Wick JB, Han Q, Xu M, Tan Y and Schold SC: Synergy between methionine stress and chemotherapy in the treatment of brain tumor xenografts in athymic mice. Cancer Res 61: 4017-4023, 2001. PMID: 11358820.

49 Tan Y, Sun X, Xu M, Tan XZ, Sasson A, Rashidi B, Han Q, Tan XY, Wang X, An Z, Su FX and Hoffman RM: Efficacy of recombinant methioninase in combination with cisplatin on human colon tumors in nude mice. Clin Cancer Res 5: 21572163, 1999. PMID: 10473100.

50 Yang Z, Wang J, Lu Q, Xu J, Kobayashi Y, Takakura T, Takimoto A, Yoshioka T, Lian C, Chen C, Zhang D, Zhang Y, Li S, Sun X, Tan Y, Yagi S, Frenkel EP and Hoffman RM: PEGylation confers greatly extended half-life and attenuated immunogenicity to recombinant methioninase in primates. Cancer Res 64: 6673-6678, 2004. PMID: 15374983.

51 Tan Y, Zavala J, Han Q, Xu M, Sun X, Tan XZ, Tan X, Magana $\mathrm{R}$, Geller $\mathrm{J}$ and Hoffman RM: Recombinant methioninase infusion reduces the biochemical endpoint of serum methionine with minimal toxicity in high-stage cancer patients. Anticancer Res 17: 3857-3860, 1997. PMID: 9427792.

52 Tan Y, Zavala S, Xu M, Zavala J and Hoffman RM: Serum methionine depletion without side effects by methioninase in metastatic breast cancer patients. Anticancer Res 16: 3937-3942, 1996. PMID: 9042316.

53 Sun X, Tan Y, Yang Z, Li S and Hoffman RM: A rapid HPLC method for the measurement of ultra-low plasma methionine concentrations applicable to methionine depletion therapy. Anticancer Res 25: 59-62, 2005. PMID: 15816519.

54 Sugimura T, Birnbaum SM, Winitz M and Greenstein JP: Quantitative nutritional studies with water-soluble, chemically 
defined diets. VIII. The forced feeding of diets each lacking in one essential amino acid. Arch Biochem Biophys 81: 448-455, 1959. PMID: 13638009.

55 Chello PL and Bertino JR: Dependence of 5-methyltetrahydrofolate utilization by L5178Y murine leukemia cells in vitro on the presence of hydroxycobalamin and transcobalamin II. Cancer Res 33: 1898-1904, 1973. PMID: 4737200.

56 Halpern BC, Clark BR, Hardy BN, Halpern M and Smith RA: The effect of replacement of methionine by homocystine on survival of malignant and normal adult mammalian cells in culture. Proc Natl Acad Sci 71: 1133-1136, 1974. PMID: 4524624.

57 Gao X, Sanderson SM, Dai Z, Reid MA, Cooper DE, Lu M, Richie JP Jr, Ciccarella A, Calcagnotto A, Mikhael PG, Mentch SJ, Liu J, Ables G, Kirsch DG, Hsu DS, Nichenametla SN and Locasale JW: Dietary methionine influences therapy in mouse cancer models and alters human metabolism. Nature 572: 397401, 2019. PMID: 31367041 . DOI: 10.1038/s41586-019-1437-3

58 Wang Z, Yip LY, Lee JHJ, Wu Z, Chew HY, Chong PKW, Teo CC, Ang HY, Peh KLE, Yuan J, Ma S, Choo LSK, Basri N, Jiang X, Yu Q, Hillmer AM, Lim WT, Lim TKH, Takano A, Tan EH, Tan DSW, Ho YS, Lim B and Tam WL: Methionine is a metabolic dependency of tumor-initiating cells. Nat Med 25: 825-837, 2019. PMID: 31061538. DOI: 10.1038/s41591-0190423-5

59 Hoshiya Y, Guo H, Kubota T, Inada T, Asanuma F, Yamada Y, Koh J, Kitajima $\mathrm{M}$ and Hoffman RM: Human tumors are methionine dependent in vivo. Anticancer Res 15: 717-718, 1995. PMID: 29572800. DOI: 10.1007/978-1-4939-7745-1_1
60 Hoshiya Y, Kubota T, Matsuzaki SW, Kitajima M and Hoffman RM: Methionine starvation modulates the efficacy of cisplatin on human breast cancer in nude mice. Anticancer Res 16: 35153517, 1996. PMID: 9042214.

61 Hoshiya T, Kubota T, Inada T, Kitajima M and Hoffman RM: Methionine-depletion modulates the efficacy of 5-fluorouracil in human gastric cancer in nude mice. Anticancer Res 17: 43714376, 1997. PMID: 9494535.

62 Jacobsen SJ, Hoffman RM and Erbe RW: Regulation of methionine adenosyltransferase in normal diploid and simian virus 40-transformed human fibroblasts. J Natl Cancer Inst 65(6): 1237-1244, 1980. PMID: 6253712.

63 Kreis $\mathrm{K}$ and Hession $\mathrm{C}$ : Isolation and purification of $\mathrm{L}-$ methionine-alpha-deamino-gamma-mercaptomethane-lyase (Lmethioninase) from Clostridium sporogenes. Cancer Res 33: 1862-1865, 1973. PMID: 4720797.

64 Tanaka H, Esaki N, Yamamoto T and Soda K: Purification and properties of methioninase from pseudomonas ovalis. Febs Lett 66: 307-311, 1976. PMID: 955094.

65 Komiya A, Shimbo M, Suzuki H, Imamoto T, Kato T, Fukasawa S, Kamiya N, Naya Y, Mori I and Ichikawa T: Oral low-dose dexamethasone for androgen-independent prostate cancer patients. Oncol Lett 1: 73-79, 2010. PMID: 22966259.

Received February 29, 2020

Revised March 17, 2020

Accepted March 23, 2020 